\title{
Management Effectiveness and Its Impact on Quality of Work Life in Higher Education: Lecturer Perspectives
}

\author{
Mochamad Rizki MBA* \\ Faculty of Business and Management, Universitas Mercu Buana \\ Jalan Meruya selatan No. 1, Jakarta Barat, Indonesia \\ Prof. Dr. Yetti Supriyati M.Pd \\ Postgraduate Studies, State University of Jakarta \\ Kampus A Universitas Negeri Jakarta \\ Gedung Bung Hatta Pascasarjana UNJ \\ Jl. Rawamangun Muka, Jakarta Timur 13220 \\ Prof. Dr. Maruf Akbar \\ Postgraduate Studies, State University of Jakarta \\ Kampus A Universitas Negeri Jakarta \\ Gedung Bung Hatta Pascasarjana UNJ \\ Jl. Rawamangun Muka, Jakarta Timur 13220
}

\begin{abstract}
Quality of work life is a working condition as a result of interaction between the individual and his work so as to make workers more productive and satisfy. The aim of this study is to find out effective management and work culture affect lectures quality of work life in Universitas Mercu Buana Jakarta. Effective management is how the school management maintaining its lecturers. The work culture is a work culture already specified from the university, namely, creative, discipline, honest, responsible, environmental friendly and local wisdom. The research technique was a quantitative approach with sample and questionnaires distributed to 220 lecturers. Data collection from quality of work life, management effectiveness and work culture were analyzed and compare to given number from statistical tables. The research concluded that the impact of effective management, and work culture toward quality of work life is positive in the level of $5 \%$ error.
\end{abstract}

Keywords: Quality of work life, Management Effectiveness, Work Culture

DOI: $10.7176 / \mathrm{EJBM} / 11-29-07$

Publication date:October $31^{\text {st }} 2019$

\section{Introduction}

In the trend of shifts from setting to technology in a number of ways as well as the rise of worker unions, employers suggest wages as compensation and also generate particular advantages creating a quality working atmosphere that will fascinate and maintain their brains at the fields. In the past, the concepts of the quality of work life were researched by many researchers through all the dimensions of quality of work life. Hian and Einstein have indicated the original term "Quality of Work Life" (QWL) as first being introduced in 1972 (Hian and Einstein, 1990). The definition of Quality of working life is as need satisfaction getting from an interaction of employees' basic needs such as survival and self-actualization needs and others correlated resources of organizations for meeting them.

Quality of work life is a management system approach or perspective of the organization that aims to improve the quality of life of employees in the work environment in a simultaneous and continuous way. Quality of work life can be carried out by providing a feeling of security at work, job satisfaction, respect for work and creating conditions for growth and development so as to increase the dignity and employees. According to Amin (2013), There are three distinctive elements of quality of work life: (1) a concern about the effect of work on people as well as organizational effectiveness, (2) the idea of worker participation in organizational problem solving and decision making and (3) the creation of reward structures in the workplace which consider innovative ways of rewarding employee input into the work process such as gain sharing. According to Cascio in Arifin (2012), the quality of work life is the perception of employees that they want to feel safe, relatively satisfied and have the opportunity to be able to grow and develop as humans. Andanna and Griffin (2013) stated that quality of work life as a concept which is life satisfaction as the highest level, and job satisfaction is in the middle.

Professional lecturers are teachers who have good self-quality in carrying out his profession as a person who performs an example for students. Therefore higher education organizations such as universities have to be more active in improving the quality of lecturers in Indonesia. Lecturers must continue to update their performance and knowledge. This is due to lecturer is a pioneer of education that is a role model for every student. One of the determinants of good and bad lecturer in teaching is quality of work life. The implementation of quality of work 
life in the higher education environment is expected to continue to maintain and improve the lecturer performance in making the maximum effort for the progress and development of the university. This issue would lead to attain university vision and mission.

\subsection{Research Objectives}

Research objective in this paper is to find out management effectiveness and work culture affecting quality of work life. Lack of management effectiveness creates low willingness in teaching. Management usually is busy with their routines and has insufficient time to give attention to lecturers. Second factor is work culture that has not been fully implemented. Lecturers are not comprehended and implement University's work culture into their way of teaching. Lecturer's quality of work life is a factor that determines the lecturer's performance. The university has not maintained lecture's quality of work life. Lecturer does not have enough time and lack of facilities to explore and expand their creativities. This creativity will have a positive impact on students in delivering opinions on the material provided.

\subsection{Research Question}

Basically, quality of work life not only influenced by management effectiveness and work culture, but also influenced by broader and more complex factors. Because of time limitation to conduct the studies, management effectiveness, work culture and quality of work life lecturers are variables researched. We set up management effectiveness as independent variable, conversely work culture and quality of work life as dependent variables. There are three questions in this research to find the effect of independent variable to dependent variables.

1. Does management effectiveness affect quality of work life?

2. Does work culture have a direct effect quality of work life?

3. Does management effectiveness affect work culture?

Each of the questions above is analyzed and tested. Statistical method of analyzing was used in obtaining the answer for the above questions. We tested lecturers from Universitas Mercu Buana using questionnaires. The results were analyzed by comparing to benchmark numbers from statistical table. The research results would perform a better idea for Universitas Mercu Buana and other education institutions on further teaching method development.

\subsection{Research Background}

According to Gibson (2009), the nature of managerial work is then to coordinate the work of individuals, groups and organizations by performing four management functions: planning, organizing, leading and controlling. In addition Terry (2006) has theory that management function are planning, organizing, actuating and controlling. Furthermore, the nature of effectiveness from Bacal (2012) means an effective system helps organizations, managers, and employee succeed. It helps the organization meets short and long term goals and objectives by helping managers and employees do their jobs better. Sharpe (1993) wrote that effective management requires defining and redefining the mission and activities of the organization. The manager must keep in close contact with the needs and views of both staff and customers while designing and executing programs. It is the responsibility of the manager to ensure that the organization's performance results in accomplishments and products that serve public needs. The essence of management is how one could manage based on planning, organizing, actuating and controlling. These functions have to be performed orderly and carefully implemented to get the best result. If there is a failed in any of the function then the process has to be evaluated and corrected. Effective is usually associated with efficient. Effective means something is done according to standard or objective which has been set. When a patient is treated and has to stay a few days in a hospital. She is recovering in two days. The process that making the patient recovered is effective. However, when the patient can be recovered without staying in the hospital means efficient. According to Griffin (2013), effective management is making the right decisions and successfully implementing them. Effective management according to Tampubolon (2008) is influenced by three factors, namely the effectiveness of organizations, groups and individuals. Effective organization can be measured by looking at the extent to which the organization can achieve its stated objectives Robbins in Kurniawan (2012) said that work culture is built and maintained based on the philosophy of the founder or company leader. This culture is strongly influenced by the criteria used in hiring process. The actions of the leader will greatly influence the behavior that can be accepted or that cannot be accepted by workers. The form of socialization will depend on the success achieved in setting values in the selection process. But slowly these values will automatically be selected to make adjustments to changes, which will eventually emerge the desired work culture. The color of work culture according to Triguno in Arianto (2013) is productivity in the form of work behavior that can be measured, among others: hard work, tenacious, disciplined, productive, responsibility and motivation, benefit, creative, dynamic, consistent, consistent, responsive, and independent and be a better person. According to Wibowo (2013) culture in an organization, both government and private organizations reflect the appearance of the organization, how the organization is seen by people who are outside. Organizations that have 
a positive culture will show a positive image. Tampubolon (2013) wrote in his book entitled Organizational Behavior, organizational culture can be the basis of behavior for all team members and groups in achieving the organization's final goals. Organizational culture can be an element that maintains the stability of employees in behaving in carrying out organizational functions. The concept of work culture according to Sedarmayanti (2007), the work culture of human resources is a life attitude and a human way of life that is based on a life view that rests on the value of commendable behavior that is generally accepted and has become the nature, habits and driving force positive power in humans to always succeed at work. Universitas Mercu Buana has implemented work culture among employee and worker that consists of six actions, namely, honest, disciplined, responsible, creative, local wisdom and environmentally friendly. This work culture is written in the employee guidance book and hanging in some of the walls in the classes.

According to Rose in Amin (2013), There are three distinctive elements of quality of work life related interventions: (1) a concern about the effect of work on people as well as organizational effectiveness, (2) the idea of worker participation in organizational problem solving and decision making and (3) the creation of reward structures in the workplace which consider innovative ways of rewarding employee input into the work process such as gain sharing. Reddy (2010) said, quality of work life is the degree to which work in an organization contributes to material and psychological wellbeing of its members. Amstrong (2009), the quality of working life is related to the basic of extrinsic job factors of wages, hours, and working conditions and the intrinsic factors of job itself, focused their definition on work involvement, intrinsic job motivation, job satisfaction and happiness. Ventegodt and Merrick (2009) describe quality of work consists of four basic conditions, personal quality of life, mastery of the working process, fellowship with colleagues and management and creating real value for both customers and environment. According to Cascio in Arifin (2012), the quality of work life is the perception of employees that they want to feel safe, relatively satisfied and have the opportunity to be able to grow and develop as humans. Andanna and Griffin (2013) stated that quality of work life as a concept which is life satisfaction as the highest level, and job satisfaction is in the middle. It is very important matter and is a necessity for the company to attract and retain its employees so that they are loyal to the company. Managers are trying to reduce the dissatisfaction with the quality of work life of their employees. The goal of quality of work fife is to develop the best possible working environment for all members of the organization to support the health of the company's environment. In addition can increase the loyalty of workers to serve the company, work with enjoyment and be safe so that it influences a good work climate that will impact on effectiveness and productivity. Workers are motivated to innovate and be more creative. Benefits such as ensuring their welfare, having a climate and good working conditions will ultimately creating a psychological impact on the person own work.

Hypothesis 1 is management effectiveness affecting quality of work life. Quantitative method of research from Bachri (2015) with title of Effect of Demographic Characteristics and Organizational Climate on Quality of Work Life proved that there is an impact from management effectiveness to quality of work life. Further research from Paseki (2013) with title Quality of Work Life and Employee Performance against Career Development at the Regional Office of the Directorate General of State Assets Suluttenggo Malut in Manado proves that there is a significant effect of the quality of work life and employee performance on employee career improvement. The research used quantitative method of analysis with government officials as sample.

Hypothesis 2 is work culture affecting quality of work life. Gifford (2002) in his research with title The Relationship between Hospitals Unit Culture and Nurses' Quality of Work life proved that work culture is affecting quality of work life. The research was conducted at hospitals in the United States. It used statistical method of analysis. Idrus (2006) with research title Implications of Organizational Climate towards Job Satisfaction and Quality of Employee Work Life concluded that there work culture is affecting quality of work life. The research used company's employee as sample.

Hypothesis 3 is management effectiveness affecting work culture. Research done by Tjihajadi (2007) with title The Importance of Cultural Position and Organizational Effectiveness in Competition proved that the hypothesis is true meaning that management effectiveness is affecting work culture. This research was conducted by comparing organizations in Japan, South Korea and Indonesia. The results from observations is national customs have an important role in the existing organizational culture. Therefore, it is necessary to find and develop an organizational culture that fits the national personality. This condition will increase the effectiveness of the organization. Based on the explanation in this study, it can be concluded that the organizational culture of various organizations around the world has a very important contribution in creating organizational effectiveness that supports organizational success. This research suggested that the need for an organizational culture embedded in the employee's heart. Furthermore, the culture itself should be inherent, understood and lived out by all members of the organization. Subsequent research was written by Armia (2002) with the title The Effect of Culture on Organizational Effectiveness: Hofstede's Cultural Dimension. The result from this research is there was the effectiveness of organizations, especially educational organizations, is strongly influenced by culture. This study uses a type of educational organization using an authoritarian model, with organizational leaders being the command center of the entire organization. In addition, this organization has been established for a long time, so 
the organizational culture has been well formed.

Figure 1 Research Framework

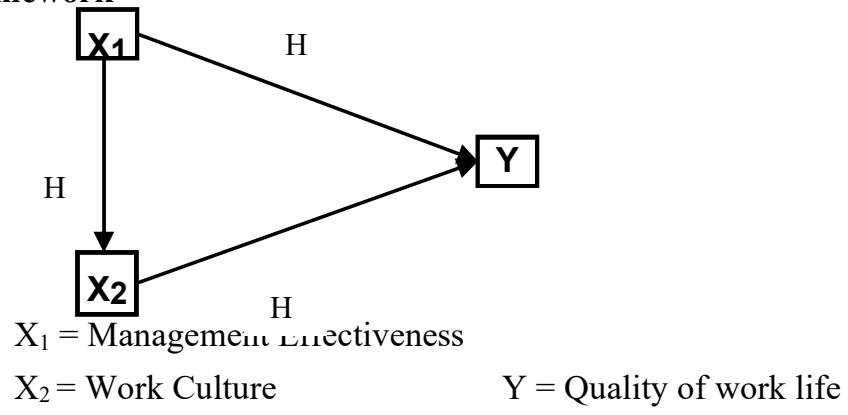

The first path represents hypothesis 1 from management effectiveness (X1) as independent variable to quality of work life as dependent variable. Second path represents hypothesis 2 from work culture (X2) as dependent variable to quality of work life (Y) as dependent variables. Third path is management effectiveness (X1) as independent variable to work culture (X2) as dependent variable.

\section{Methodology}

The causality model is used in this study. Technique of analysis used is Structural Equation Modelling (SEM) operated by SPSS and Microsoft Excel. Modelling studies through SEM allows researchers to answer the research questions which are dimensionally (ie measure what the indicators of a concept) and regression (measure of influence or degree of relationship between the factors that the dimensions have been identified). Ferdinand (2006) stated several reasons for the use of SEM program as an analytical tool due its compatibility for:

1. Confirming non-dimension of various indicators to a dimension/construct/concept/factor.

2. Testing suitability or provision of a model based on empirical data.

3. Examining the suitability of the model as well as the causality relationship between the factors constructed or observed in the research model

Confirmatory factor analysis factor analysis was used to test the indicators that make up variables of quality of work life by management effectiveness and work culture.

Questionnaire distributed to Universitas Mercu Buana lecturers by using a purposive random sampling technique. The number of sample was 220 out of 700 active e-learning lecturers as a total population. The questionnaire has 108 statements represent four variables. Each subject was requested to respond to the closest match of five-point scaled. The scale is ranging from strongly disagree (1), disagree (2), neutral (3), agree (4) and strongly agree (5).

Further test is data analysis. Data analysis is the process of inspecting, cleaning and transforming data with the objective of making it useful for research. Collected data were tested and analyzed. Test includes reliability, validity and normality. The results were compared with data analysis thresholds. We found all data are passed and useable for testing the hypotheses.

\section{Discussion and Conclusion}

This section presents the results of the analysis and describe of the research data description. It includes the prerequisite test for the analysis and hypothesis test. Data description consists of distribution of the average value, standard deviation, median variance, mode, minimum value and maximum value. Prerequisite analysis test must be carried out and met several requirements. The tests are regression test with significant value, linear values and regression equation of each research path with normal data residual distribution.

This research is to find out the effect of independent variable management effectiveness (X1) on dependent variables, work culture (X2) and Quality of work life (Y). We used linear regression to find out the effect of each variable into another. Regression can be carried out with normality and validity. These processes had been done and turned out the variables were normal and valid. Further tests are regression, t-test and hypothesis test. The results are presented in the bellow tables.

\subsection{Normality Test (Liliefors)}

Normality test is an analysis to test whether data comes from populations that are normally distributed. Normality test is important because most inferential statistical analysis requires data that is normally distributed. Normal distribution testing with Lilliefors test is generally used for single data. 
Table 1 Normalization

\begin{tabular}{lllllll}
\hline No & Regression & $\mathbf{N}$ & L $_{\text {test }}$ & \multicolumn{2}{l}{ Ltable } & Comment \\
\cline { 4 - 5 } & & & $\alpha=5 \%$ & $\alpha=1 \%$ & \\
\hline $\mathbf{4}$ & Y on $\mathrm{X}_{1}$ & 220 & 0.0384 & 0.0597 & 0.073 & Normal \\
$\mathbf{5}$ & Y on $\mathrm{X}_{2}$ & 220 & 0.0369 & 0.0597 & 0.073 & Normal \\
$\mathbf{6}$ & $\mathrm{X}_{2}$ on $\mathrm{X}_{1}$ & 220 & 0.0498 & 0.0597 & 0.073 & Normal \\
\hline
\end{tabular}

$\mathrm{X}_{1}=$ Effective management, $\mathrm{X}_{2}=$ Work culture, $\mathrm{Y}=$ Quality of work life

The test was taken with level margin of error $1 \%$ and $5 \%$. Notation $\mathrm{N}$ means number of sample. L-test is the result from calculation and L-table is numbers from statistical table. According to calculation and comparing the L-test and L-table, all the L-test numbers fall below L-table meaning that the data is normally distributed. The highest number is number 6 which is 0.0498 and the lowest is number 5 which is 0.0369 .

\subsection{Regression Result}

Regression test is to find out the relationship on one variable to another variable based on research diagram. If the result is positive meaning that any increase in variable will increase another variable. We calculated regression line for each line between variables and the results are shown below.

Table 2 Regression Result

\begin{tabular}{|c|c|c|c|c|c|c|}
\hline \multirow[b]{3}{*}{ Reg } & \multirow[b]{3}{*}{ Regression Result } & \multicolumn{2}{|c|}{ Regression Test } & \multicolumn{2}{|c|}{ Linearity Test } & \multirow[b]{3}{*}{ Result } \\
\hline & & $F_{\text {test }}$ & Ftable & $F_{\text {test }}$ & $F_{\text {table }}$ & \\
\hline & & & $\alpha=0.01$ & & $\alpha=0.05$ & \\
\hline Yon $X_{1}$ & $\widehat{\mathrm{Y}}=46.663+0.469 \mathrm{X}_{1}$ & 68.13 & $6.75 * *$ & 1.314 & $1.47^{\mathrm{ns}}$ & Positive \\
\hline$Y$ on $X_{2}$ & $\widehat{\mathbf{Y}}=31.104+0.471 \mathrm{X}_{2}$ & 77.88 & $6.75 * *$ & 1.117 & $1.45^{\mathrm{ns}}$ & Positive \\
\hline$X_{2}$ on $X_{1}$ & $\widehat{X}_{2}=76.690+0.559 X_{1}$ & 74.58 & $6.75 * *$ & 1.287 & $1.47^{\mathrm{ns}}$ & Positive \\
\hline
\end{tabular}

Regression test shows positive effect on variable $X_{1}, X_{2}$, and $Y . X_{1}$ is management effectiveness, $X_{2}$ is work culture, and $\mathrm{Y}$ is Quality of work life. This shows any additional effort on each variable would give positive impact on other variable. Regression test shows significant value for each regression line. Linearity test shows the distribution of estimated points forms an acceptable linear line. The point distribution approaches linear regression equation. Both numbers from regression test and linearity test are compared and when they meet the criteria, they have a positive value of regression.

\section{3. t-Test Result}

The t-test is known as a partial test, which is to confirm the hypothesis. Results from analysis are compared to number from table ( $t$ table). Calculation from t-test is shown below:

\section{Table 3 T-test Result \\ Hypothesis Path}

Coefficients

\begin{tabular}{lllll}
\hline $\mathrm{X}_{1}$ on $\mathrm{Y}$ & 0.307 & 4.79 & 1.97 & $\begin{array}{l}\mathrm{H}_{0} \text { is rejected, } \mathrm{H}_{4} \text { is accepted. There is a direct positive effect } \\
\text { of } \mathrm{X}_{1} \text { on } \mathrm{Y}\end{array}$ \\
$\mathrm{X}_{2}$ on $\mathrm{Y}$ & 0.358 & 5.57 & 1.97 & $\begin{array}{l}\mathrm{H}_{0} \text { is rejected, } \mathrm{H}_{5} \text { is accepted. There is a direct positive effect } \\
\text { of } \mathrm{X}_{2} \text { on } \mathrm{Y}\end{array}$ \\
$\mathrm{X}_{1}$ on $\mathrm{X}_{2}$ & 0.505 & 8.64 & 1.97 & $\begin{array}{l}\mathrm{H}_{0} \text { is rejected, } \mathrm{H}_{6} \text { is accepted. There is a direct positive effect } \\
\text { of } \mathrm{X}_{1} \text { on } \mathrm{X}_{2}\end{array}$ \\
\hline
\end{tabular}

t-test shows positive effect on variable $X_{1}, X_{2}$, and $Y . X_{1}$ is management effectiveness, $X_{2}$ is work culture, and $\mathrm{Y}$ is Quality of work life. The values of $t$-test are higher than $t$-table, meaning that alternative hypotheses are accepted. In other words each variable observed is affected another variable. This result confirmed the hypothesis stated above.

First hypothesis test indicated that management effectiveness has a significant influence on quality of work life. The result showed that the more effective management from the university in managing learning process, the higher the quality of work life for lecturers. Management effectiveness reflects a success that is characterized by the achievement of organizational goals. Companies are required to support working conditions that are safe and provide adequate working equipment for employees in completing their work. Safety includes the absence of sudden termination of employment (layoffs). Employees who work safely and be able to manage their work efficiently are also part of the quality of work life. Sense of secure and efficient in working can arouse work spirit for employees. In addition companies can utilize employees' skills and abilities and provide an environment that encourages them to improve their skills and abilities. The company is expected to be able to utilize employee capabilities rather than using company abilities. According to Cascio in Arifin (2012), states that the quality of work life is the perception of employees that they want to feel safe, relatively satisfied and have the opportunity to be able to grow and develop as a human being. 
Second hypothesis is indicated that work culture has a significant influence on quality of work life. From this analysis, one can increase the quality of work life if there is a higher concern of work culture. The work culture of an organization is determined by organizational culture, the organizational culture itself according to Robbins (2013) first, is a perception, not something that can be touched or seen physically, but employees receive and understand it through what they experience in the organization. Second, the organizational culture is descriptive, which is related to how members accept and interpret the culture, regardless of whether they like it or not. Finally, even though individuals in organization have different backgrounds and work at different organizational levels, they tend to interpret and express organizational culture in the same way. Universitas Mercu Buana has six pillars of work cultures namely, honest, disciplined, responsible, creative, local wisdom and environmentally friendly. Applying these six pillars effectively will increase quality of lecturer life.

Third hypothesis is indicated that management effectiveness has a significant influence on work culture. If there is an increase in management effectiveness, there will be an increase in work culture. Effective is a variable derives from a management goal focuses on the expected results, objectives and targets. Effective organizations are organizations that established success in inputs, processes, outputs, and outcomes. It is characterized by the quality of these indicators. The effectiveness of a university is not only achievement of targets and fulfillment of various needs, but also it is closely related to quality, or in other words the establishment of quality development of educational institutions. A theory revealed by Tampubolon (2008) the task of management is to find out how to increase the effectiveness of individuals, groups, and organizations. This is due to organizations as a tool for carrying out community work is that the organization can do more work than individual. Effective managers are able to choose the right thing to do and the right method to get the most optimal results. Manager should focus on planning, organizing, actuating and controlling. When these factors are achieved then a company will achieve its goal effectively.

\section{Conclusion and Recommendation}

Conclusion from the analysis shows better management effectiveness will improve lecturer quality of work life and work culture. Management effectiveness for instance better planning preparation in academic work such as class scheduling, teaching materials and learning objective. Better planning includes lecturer involvement in class planning or creating plan list in line with lecturer background, experience and schedule. Freedom in choosing teaching material is also part of management effectiveness. Remove the hierarchy and build a trust. This creates better intimacy and flow of ideas.

Lecturer training in work culture may increase awareness for discipline, honest, responsible, and creative and better knowledge of environment friendly and local wisdom. Health and safe working condition training is a part of lecturer awareness in work culture. Lecturer may have better idea of how to work safely and healthy. University should stick more written work culture on the walls so it can be seen by the lecturer. This may unify a culture and awareness of how to behave according to university culture.

Adequate amount of time staying at home and spare more time with family would create a better quality of life. Sometimes lecturer has an overload teaching time. This condition might embark to tiredness and less spare time. Adding more facilities for lecturers such as more relax library environment and collecting an up to date reading materials would give lecturers a time to read and relax targeted to have better quality of life. University offers flexible time for telecommuting and compressed workweeks. Even in more firm environments or positions where extensive flexibility isn't difficult, lecturers can still try to improve. This action may include leaving the office early in the purpose of family commitment or less official dress and permitting lecturer a day off for the birthday.

There are still many factors would affect quality of work life which might be addressed for further research. This research is limited to management effectiveness, work culture and quality of life. May this research would give a better idea of how to increase lecturer quality of work life in university environment.

\section{References}

Arianto, Dwi Agung Nugroho, (2013) The Effect of Discipline, Work Environment and Work Culture on Teacher Performance, Journal Economia, Vol. 9, No. 2

Arifin, Noor,(2012) Analysis of the Quality of Work Life, Performance, and Job Satisfaction at CV. Duta Senenan Jepara, Journal Economia. Vol. 8, No. 1, April.

Armia, Chairumam, The Effect of Culture on Organizational Effectiveness: Hofstede's Cultural Dimension, JAAI, Vol. 6, No. 1 Juni 2002.

Armstrong, Michael, Amstrong's, (2009) Handbook of Human Resource Management Practice, 11th edition, London: Kogan Page

Bacal, Robert, (2012), Performance Management, 2th edition, Madison: Mc Graw Hill, 2012.

Brahmasari, Ida Ayu and Agus Suprayetno, (2008) The Effect of Work Motivation, Leadership and Organizational Culture on Employee Job Satisfaction and Its Impact on Company Performance (Case study at PT. Pei Hai 
International Wiratama Indonesia), Journal Management and Entrpreneurship, Vol. 10, No. 2, September

Febriana, Irwanti Martha and Ayu Aprilianti, (2012) Analysis of the Effect of Quality of Work Life on Employee Engagement Case Studies at American Petroleum Company Indonesia, Journal Academia,

Frinaldi, Aldri and Muhamad Ali Embi, Effect of Ethnic Work Culture on Courage Work Culture and Wisdom of Civil Servants in Excellent Public Service (Study on West Pasaman District Government), Proceeding and Symposium National and Local Autonomy, FISIP UNTIRTA.

Gaol, Jimmy L., (2014) A to Z Human Capital: Human Resource Management, Jakarta: Grasindo,

Gibson, (2009) Organizations, Behavior, Structure and Process, Singapore: Mc Graw Hill

Gifford, Blair D., (2002) The Relationship Between Hospitals Unit Culture and Nurses' Quality of Work life, Journal of Health Care Management, Vol. 47, No. 1

Griffin, Ricky W., (2013) Management: Principles and Practices 11th edition, Canada: South Western Cenage Learning

Ghozali, Imam, (2014) Structural Equation Models, Concepts and Applications With the AMOS Program 22.0, Semarang: UNDIP

Ghozali, Imam, (2016) Multivariate Analysis Application with the SPSS Program, Semarang: UNDIP

Gunawan, C, and Sutanto, M., Eddy, (2013). Job Satisfaction, Organizational Commitment and Turnover Intentions, Journal Economic and Business Management Partners, Vol. 4, No.1, pp. 76-88

Herlina, Tini Elyn and Ahmad Alim Bachri, (2015) Effect of Demographic Characteristics and Organizational Climate on Quality Of Work Life (QWL) Banjarmasin Health Polytechnic Lecturers, Management View Journal, Vol. 3, No. 3

Herminingsih, Anik, (2014) The Effect of Human Resource Management Practices and Organizational Culture on Employee Engagement, Proceeding and Seminar Management Technology XX, Program Studi MM-ITS Surabaya, 1 Februari

Hian CC,Einstein WO. (1990) Quality of work life (QWL): What can Unions Do? SAM Advanced Management Journal; 55(2): 17 .

Husada, Dian, (1997) Human Resource Management Effectiveness as Determinants of Firm Performance, Academy of Management Journal, Vol. 40 No.1, 1997,

Huselid, Mark A., (1997) Susan E. Jackson and Radall S. Schuler, Technical and Strategic Human Resource Management Effectiveness as Determinants of Firm Performance, Academy of Management Journal, Vol. 40, No. 1

Husnawati, Ari, (2006) Analysis of the Effect of Quality of Work Life on Employee Performance with Commitment and Job Satisfaction as Variable Intervening (Study on PERUM Pegadaian Kanwil VI Semarang), Thesis, Program Pasca Sarjana Univeristas Dipenogoro Semarang

Idrus, Muhammad, (2006) Implications of Organizational Climate Towards Job Satisfaction and Quality of Employee Work Life, Psychology Journal Universitas Diponegoro, Vol. 3, No. 1, Juni

Indonesian Regulation on National Education System , No. 20 year of 2003.

K, Andana, and Griffin, R.W., (2013) Quality of Work Life in Indonesian Public Service Organizations: The Role of Career Development and Personal Factors, ed. Zulkarnain Amin, International Journal of Applied Psychology, Vol. 3 No. 3

Kurniaiwan, Dedi, A. Rahman Lubis, and Muhammad Adam, (2012) The Effect of Work Culture and Work Motivation on the Performance of Banda Aceh International Federation Red Cross Employees, Graduate Student Journal, Universitas Syah Kuala, Vol. 1, No. 1

Center of Materials Learning, (2016) Universitas Mercu Buana Jakarta

Naidoo, Ashnee dan Nico Martins, Investigating The Relationship Between Organizational Culture and Work Engagement, Problems and Perspectives in Management, Volume 12, Issue 4, 2014, pp. 433-441

Noe, Raymond A., (2010) Human Resource Management: Achieve Competitive Advantages, Jakarta: Salemba Empat,

Noor, Juliansyah,, (2014) Research Methodology, Jakarta: Kencana

Parmin, (2012) Effect of Quality of Work Life, Work Discipline and Competence on Employee Performance at PD. BPR Kebumen BKK, Business Focus Journal, Vol. 14, No. 02, December

Paseki, Fabian Michele, (2013) Quality of Work Life and Employee Performance Against Career Development at the Regional Office of the Directorate General of State Assets Suluttenggo Malut in Manado", EMBA Journal, Vol. 1, No. 4, December

Reddin, (1996) The Impact of Stress in Site Management Effectiveness eds. Ramdani Djebarni, Contruction Management and Economic Journal, July Edition

Reddy, Lokanadha, M. and Mohan Reddy.P , (2010) Quality Of Work Life Of Employees: Emerging Dimensions, Asian Journal Of Management Research

Robbins, Stephen P. and Mary Coulter,(2013) Management, 11th edition, England: Pearson

Robbins, Stephen P. and Mary Coulter, (2010) Management, Translation by Bob Sabran and Wibi Hardani, ed. 
10, Jakarta: Erlangga.

Rudito, Bambang, (2009) Building the Orientation of Corporate Culture, Bandung: Rekayasa Sains Santoso, Singgih, (2014) AMOS 22 For Structural Equation Model, Jakarta: Elex Media Komputindo,

Saptoto, (2014) The Effect of Transformational Leadership on Organizational Culture and Innovation at PT NEC Indonesia, Thesis, Universitas Mercu Buana Jakarta, 2014.

Sedarmayanti, (2007) Human Resource Management, Bureaucratic Reform and Civil Servants Management, Bandung: PT. Refika Aditama

Sharpe, M. E., (1993) Defining and Measuring Effectiveness in Public Management, Public Productivity and Management Review, Vol. 17, No. 1, Autumn

Soedijarto, (2008) Foundation and Direction of Our National Education, Jakarta: Kompas Media Nusantara, p. 36

Soewadji, Jusuf, (2012) Introduction to Research Methodology, Jakarta: Mitra Wacana Media

Sugiyono, (2013) Business Research Method, Bandung: Alfabeta

Tampubolon, Manahan P., (2008) Organization Behaviour, $2^{\text {nd }}$ edition, Bogor: Ghalia Indonesia

Terry, George R. (2006) Management Principles, Jakarta: Bumi Aksara

Tjihajadi, Semuil,(2007) The Importance of Cultural Position and Organizational Effectiveness in Competitio Journal Management, Vol. 6, No. 2

Truss, Catherine, David Mankin and Clare Kelliher, (2012) Strategic Human Resource Management, Oxford: University Press,

Ventegodt ,Søren and Joav Merrick, (2009) Understanding Quality Of Working Life - How To Be Happy At Work, New York: Nova Science Publisher

Wibowo, (2013) Work Culture, Jakarta: Raja Grafindo Perkasa, 